\title{
Salivary Testosterone and Cortisol Measurement in Sports Medicine: a Narrative Review and User's Guide for Researchers and Practitioners
}

Authors

Affiliations

\author{
L. D. Hayes ${ }^{1}$, N. Sculthorpe ${ }^{2}$, B. Cunniffe ${ }^{3}$, F. Grace ${ }^{4}$
}

Affiliation addresses are listed at the end of the article

Key words
androgens
exercise
sex hormone
sport
steroid

March 21, 2016

Bibliography DOI http://dx.doi.org/

10.1055/s-0042-105649

Published online:

September 27, 2016

Int J Sports Med 2016; 37: 1007-1018 @ Georg Thieme Verlag KG Stuttgart · New York ISSN 0172-4622

\section{Correspondence}

Professor. Fergal Grace Faculty of Health,

Federation University

University Drive, Mt Helen, Ballarat, Victoria

PO Box 663, Ballarat, VIC 3353

Australia

F.Grace@federation.edu.au

\section{Abstract \\ $\nabla$}

Since the initial reporting of salivary hormone measurements in marathon runners in the early 1980s, the practice of utilizing salivary testosterone (T) and cortisol (C) to reflect acute and rhythmic changes to their systemic counterparts has gained considerable momentum. However, substantial variability exists between studies with respect to methodological protocols, laboratory techniques, and interpretation of study findings. These differences can directly influence the salivary hormone values, thus hampering interpretation, limiting cross-study comparison, and constraining the generalizability of individual

\section{Glossary of Terms}

$\nabla$

C Cortisol (general term whereby the binding status of the hormone is undefined).

$\mathrm{T}$ Testosterone (general term whereby the binding status of the hormone is undefined).

Sal-C Salivary cortisol.

Sal-T Salivary testosterone.

Bio-C Bioavailable cortisol in serum. i.e., cortisol bound loosely to albumin or unbound.

Bio-T Bioavailable testosterone in serum. i.e., testosterone bound loosely to albumin or unbound.

Free-C Free cortisol in serum. i.e., unbound cortisol.

Free-T Free testosterone in serum. i.e., unbound testosterone.

TC Total cortisol. i.e., serum cortisol concentration which encompasses serum bioavailable cortisol, serum free cortisol, and serum cortisol which is bound to corticosteroid binding globulin.

Total testosterone. i.e., serum testosterone concentration which encompasses serum bioavailable testosterone, serum free testosterone, and serum testosterone which is bound to sex hormone binding globulin. study findings. This article examines the current body of literature before proposing a sequence of practical guidelines to minimize sample variability in salivary hormone research. The guidelines are grouped into 3 major categories that limit comparison between studies; A) study design, B) sample acquisition and biological variation, and C) technical and analytical error. To achieve this, the present article critically appraises research employing salivary $\mathrm{T}$ and $\mathrm{C}$ measurements, identifies potential sources of error before proposing appropriate methodological considerations for researchers and practitioners wishing to obtain $\mathrm{T}$ and $\mathrm{C}$ measurement from saliva.

\section{Introduction \\ $\nabla$}

Salivary testosterone (sal-T) and cortisol (sal-C) measurements are widely used in clinical, psychobiological, and exercise sciences as a surrogate for blood sampling. Sal-C was initially detected in the early 1960's [14,62] whilst sal-T was first reported in 1976 by Landman and colleagues [93]. In clinical settings salivary measurements are rarely used, except for the most extreme cases, such as use of sal-C for initial screening of Cushing's syndrome [114] whilst sal-T is not used at all, having recently been ruled out of diagnosing hypogonadism $[53,78]$. In contrast, sports medicine and psychobiology research have widely adopted both sal-C and sal-T [11,29,35,71-73] promoting salivary measurement from novel surrogate to pervasive biomarker largely due to the widely held assumption that they mirror their respective systemic (blood) concentrations. This has resulted in the exponential growth in popularity of sal-T and sal- $C$ in these fields, depicted by $\bullet$ Fig. 1, which represents search results using salivary search terms in PubMed, performed in all fields. Whilst these data depict all returned results, this still 


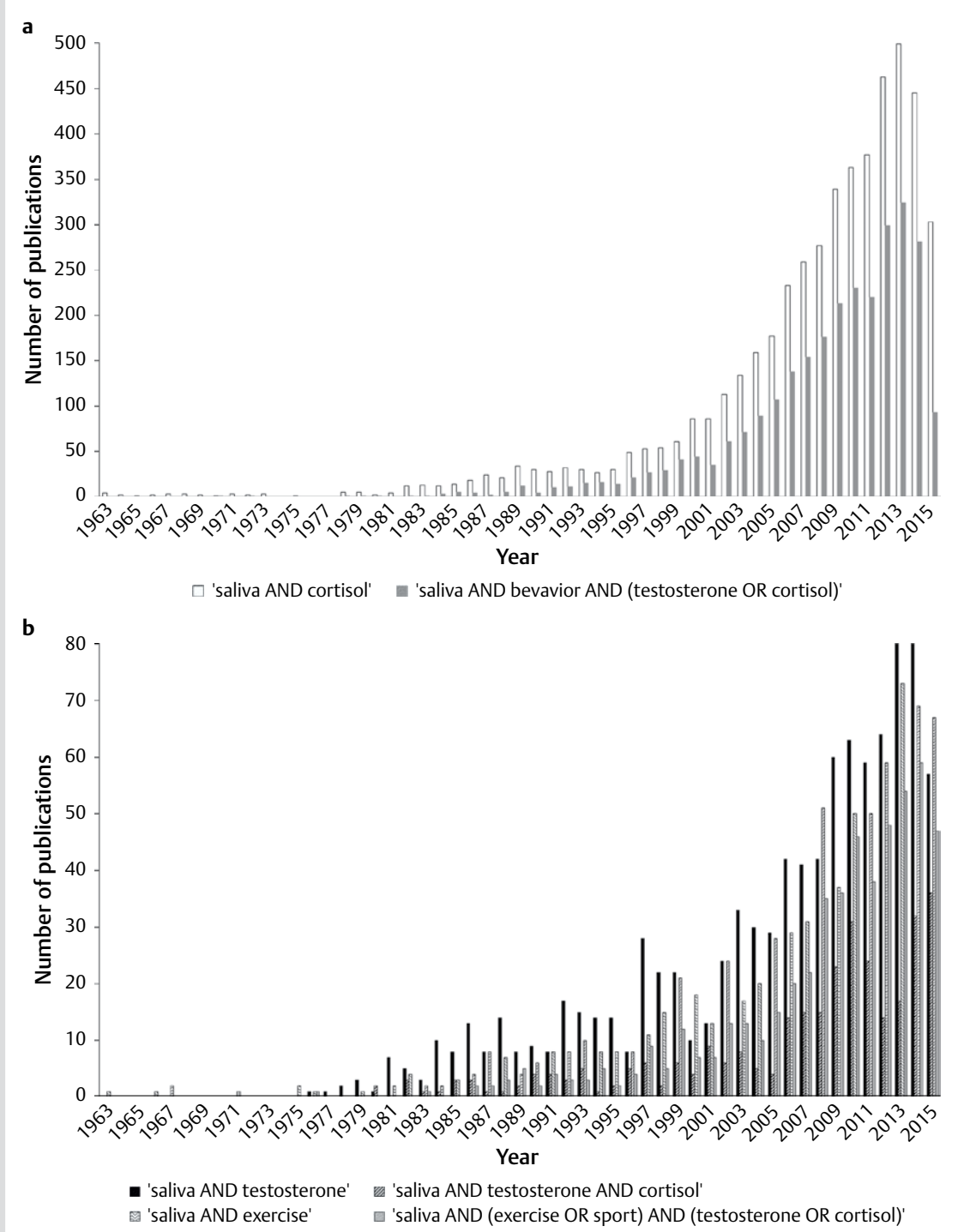

Fig. 1 a PubMed search results from $1^{\text {st }}$ January 1976 to $9^{\text {th }}$ November 2015 . Search terms were performed within all fields. Whilst these data depict all returned results, this underestimates the number of studies performed due to authors describing the measure as 'free testosterone', or 'testosterone', or 'cortisol' in their article title. b PubMed search results from $1^{\text {st }}$ January 1976 to $9^{\text {th }}$ November 2015. Search terms were performed within all fields. Whilst these data depict all returned results, this underestimates the number of studies performed due to authors describing the measure as 'free testosterone', or 'testosterone', or 'cortisol' in their article title. underestimates the total number of studies due to authors frequently omitting the term 'salivary' and describing the measure as simply 'free testosterone', or merely 'testosterone', or 'cortisol' in their manuscript title ([29,30,92] $\odot$ Table 1$)$.

Despite increased prevalence in applied research, there are multiple methodological considerations that can hinder sound interpretation of resulting sal-T and sal-C data [74,75]. Recently, the smallest observable change required before changes in sal-T and sal-C that can be considered biologically significant was determined (termed the 'critical difference' [79]) as 90\% and $148 \%$ respectively, when determined by enzyme-linked immunosorbent assay (ELISA). Moreover, Valero-Politi and FuentesArderiu [145] reported the critical difference of sal-T measured at monthly intervals to be $78 \%$, using radioimmunoassay (RIA). In both cases, these investigations were conducted in controlled laboratory environments, while conversely, investigations conducted in naturalistic settings undoubtedly exhibit a greater degree of uncontrolled variability (higher critical difference). Such studies are at greater risk of falling victim to classic 'type 1' error. In addition, a recent meta-analysis described a profound effect of study design and sampling regimen on sal-T and sal-C reactivity in response to exercise [69]. Further to the observed heterogeneity in research design, exemplars of limitations with salivary hormone interpretation in psychobiology [74], behavior [75], and endocrinology [60] have been previously acknowledged. However, drawing attention to the limitations of otherwise well-designed studies, has marginal impact to inform progress within these fields of research.

With the ultimate aim of informing progress in salivary hormone research, there has been a recent call for standardized method for measurement of sal-T and sal-C and the use of standardized control conditions, [69]. Furthermore, whilst guidelines for detection of $\mathrm{T}$ and $\mathrm{C}$ in serum are well described $[103,124,125,150]$, there are currently a lack of guidelines for detection of $\mathrm{T}$ and $\mathrm{C}$ in saliva. As such, we propose that, in the spirit of good scientific practice, it is necessary to outline a series of procedures for researchers and practitioners to adhere to when conducting salivary hormone research. These guidelines can be grouped into 3 major categories; A) Study design, B) Sample acquisition and biological variation, and $C$ ) Technical and analytical error. Each of these aspects (A, B and C) coalesce to inform comparison between studies. Therefore, the aim of this article is to provide a critical appraisal of research using salivary measurements within the field of exercise science and sports medicine, identify possible sources of error, and propose appropriate methodological procedures for researchers wishing to 
Table 1 Sources of error in sal-C and sal-T measurement and methodological and technical guidelines recommended to limit error rates. Where evidence exists that disregarding the guideline will influence sal-T and sal-C, a checked box is present. Where evidence exists that disregarding the guideline may influence sal-T or sal-C, based purely on serum data, 'evidence in TT', or 'evidence in TC' is checked.

\begin{tabular}{|c|c|c|c|c|c|}
\hline $\begin{array}{l}\text { Source of System- } \\
\text { atic Error }\end{array}$ & Guideline & $\begin{array}{l}\text { Evidence } \\
\text { in sal-T }\end{array}$ & $\begin{array}{l}\text { Evidence } \\
\text { in sal-C }\end{array}$ & $\begin{array}{l}\text { Evidence } \\
\text { in TT }\end{array}$ & $\begin{array}{l}\text { Evidence } \\
\text { in TC }\end{array}$ \\
\hline $\begin{array}{l}\text { A1 Randomised } \\
\text { Controlled Trial } \\
\text { (RCT)/Cohort Study }\end{array}$ & Is the study suitable for an RCT design? If not proceed to "collection timing". & $\checkmark$ & $\checkmark$ & & \\
\hline $\begin{array}{l}\text { A2 Collection } \\
\text { Timing }\end{array}$ & $\begin{array}{l}\text { Baseline samples collected on a control day to abrogate the anticipatory effect of } \\
\text { impending exercise/physical activity bout or challenge. Increasing the number of base- } \\
\text { line samples (i. e., on } 2 \text { separate rest days) may improve reliability but would require } \\
\text { additional financing. }\end{array}$ & $\checkmark$ & $\checkmark$ & & \\
\hline $\begin{array}{l}\text { B1 Chronological } \\
\text { Variation }\end{array}$ & $\begin{array}{l}\text { Collected sal-T and sal-C at the same time of day on each occasion (including control } \\
\text { days), during repeated measures studies. Considered circadian and seasonal pattern of } \\
\text { sal-T and sal-C release for interventions over numerous hours, and months respectively. }\end{array}$ & $\checkmark$ & $\checkmark$ & & \\
\hline $\begin{array}{l}\text { B2 Chronobiologi- } \\
\text { cal Age }\end{array}$ & $\begin{array}{l}\text { Age-matched participants for between-subject investigation. Control for age during } \\
\text { longitudinal studies. Used narrow age ranges or counterbalance studies of broad age } \\
\text { ranges. The stage of each genders' lifespan should be taken into account (E. g., andro- } \\
\text { pause, menopause). }\end{array}$ & $\checkmark$ & $\checkmark$ & & \\
\hline B3 Sex & Sal-T and sal-C not compared between sexes. & $\checkmark$ & $\checkmark$ & & \\
\hline B4 Sex; Male & $\begin{array}{l}\text { Screened for androgenic anabolic steroid use (minimum verbally) and used as exclusion } \\
\text { criteria. Used hypogonadism as exclusion criteria. }\end{array}$ & $\checkmark$ & & $\checkmark$ & \\
\hline B5 Sex; Female & $\begin{array}{l}\text { Reordered oral contraceptive pill use and stage of menstrual cycle. Used entirely pre/ } \\
\text { post-menopausal. Screened for polycystic ovary syndrome (minimum verbally) and } \\
\text { used as exclusion criteria. }\end{array}$ & $\checkmark$ & & $\checkmark$ & \\
\hline B6 Long Haul Travel & $\begin{array}{l}\text { Participants who have travelled across multiple time zones within previous } 7 \text { days or } \\
\text { spent time in hypoxic hypobaric conditions were excluded. }\end{array}$ & & $\checkmark$ & & $\checkmark$ \\
\hline B7 Dietary Intake & $\begin{array}{l}\text { Provided standardized meals or acknowledge increased biological variation. Instructed } \\
\text { participants to avoid alcohol and caffeine for } 24 \mathrm{~h} \text { before sample collection. }\end{array}$ & $\checkmark$ & $\checkmark$ & & \\
\hline $\begin{array}{l}\text { B8 Postural } \\
\text { Changes }\end{array}$ & $\begin{array}{l}\text { Where possible, ensure participants maintained their posture for the duration of sam- } \\
\text { pling. Subjects are seated or supine. }\end{array}$ & & $\checkmark$ & & $\checkmark$ \\
\hline B9 Physical Activity & $\begin{array}{l}\text { Minimized subjects' exercise } 24 \mathrm{~h} \text { prior to sampling. If not possible, recorded pro- } \\
\text { gramme variables to ensure comparability between sampling points. }\end{array}$ & $\checkmark$ & $\checkmark$ & & \\
\hline B10 Smoking & $\begin{array}{l}\text { Used as exclusion criteria. Smoking considered as significant confounder, particularly in } \\
\text { cross-sectional comparison. }\end{array}$ & $\checkmark$ & $\checkmark$ & & \\
\hline B11 Sexual Activity & Abstinence observed for $24 \mathrm{~h}$ prior to saliva collection (verbally screened). & $\checkmark$ & & $\checkmark$ & \\
\hline B12 Illness & Used as exclusion criteria. & $\checkmark$ & $\checkmark$ & & \\
\hline $\begin{array}{l}\text { B13 Psychological } \\
\text { Influence }\end{array}$ & $\begin{array}{l}\text { Familiarization with sampling was implemented. Erotic or aggressive stimulus avoided. } \\
\text { Where psychological stress is a primary outcome measure, administered a stress ques- } \\
\text { tionnaire. E. g., PSQ [155]. }\end{array}$ & $\checkmark$ & $\checkmark$ & & \\
\hline $\begin{array}{l}\text { B14 Geographical } \\
\text { Differences }\end{array}$ & $\begin{array}{l}\text { Used a homogenous group of participants. In applied settings, practitioners must be } \\
\text { aware that ethnic differences in sal-C and sal-T exist. Reported ethnic demographic in } \\
\text { methods section. }\end{array}$ & $\checkmark$ & $\checkmark$ & & \\
\hline $\begin{array}{l}\text { C1 Collection } \\
\text { Method }\end{array}$ & $\begin{array}{l}\text { Avoided use of flavored beverage crystals, gum, and lemon juice to stimulate salivary } \\
\text { flow. Dental roll, cotton swab and sugar free gum also avoided. Unstimulated saliva was } \\
\text { collected mid-flow. }\end{array}$ & $\checkmark$ & $\checkmark$ & & \\
\hline $\begin{array}{l}\text { C2 Blood Contami- } \\
\text { nation }\end{array}$ & $\begin{array}{l}\text { Participants instructed to avoid teeth brushing, hot drinks, and gum shields prior to } \\
\text { collection. }\end{array}$ & $\checkmark$ & & & \\
\hline C3 Storage & $\begin{array}{l}\text { Samples frozen quickly and stored at }-80^{\circ} \mathrm{C} \text { if storing longer than } 12 \text { months, }-20^{\circ} \mathrm{C} \text { for } \\
\text { durations below } 12 \text { months. Room temperature for storage up to } 6 \mathrm{~h} \text {. }\end{array}$ & $\checkmark$ & $\checkmark$ & & \\
\hline C4 Analysis & $\begin{array}{l}\text { Ensured samples were analyzed in the same laboratory, by the same researcher, using } \\
\text { the same assay kit. Reported coefficient of variation in all cases and not make direct } \\
\text { comparisons between techniques. }\end{array}$ & $\checkmark$ & $\checkmark$ & & \\
\hline \multicolumn{6}{|l|}{ Reporting of Data } \\
\hline R1 Study Title & $\begin{array}{l}\text { If the main outcome of the study regards sal-T or sal-C changes, then includes reference } \\
\text { to "salivary" in the title, in other cases use "salivary" as a search term (e. g., keywords). }\end{array}$ & & & & \\
\hline $\begin{array}{l}\text { R2 Use of Standard- } \\
\text { ized Reporting }\end{array}$ & $\begin{array}{l}\text { If reporting relative changes in sal-T and/or sal- } C \text { then also include absolute values } \\
\text { (mean } \pm \text { standard deviation) at each time point. }\end{array}$ & & & & \\
\hline \multicolumn{6}{|c|}{$\begin{array}{l}\text { Sources of Systematic Error: This Includes all major sources of potential imprecision (see A; B; C below) that contrive to increase measurement error in studies that employ } \\
\text { salivary hormone measurement }\end{array}$} \\
\hline \multicolumn{6}{|c|}{ A: Considerations for Study Design: These factors should inform study design. Unlike B and C, they are not always practicable } \\
\hline \multicolumn{6}{|c|}{$\begin{array}{l}\text { B: Sources of Biological Error: These factors should inform sample collection and study protocols. Sources of pre-sampling biological error should inform part of participant/ } \\
\text { athlete information sheet }\end{array}$} \\
\hline
\end{tabular}

C: Sources of Analytical Error: These factors should inform sample measurement 
Table 2 Conversion between commonly used units for salivary testosterone within physiologically observed ranges. The molecular mass of testosterone is $288.42 \mathrm{~g} \cdot \mathrm{mol}^{-1}$ and therefore $1 \mathrm{~mol}=288.42 \mathrm{~g}$. As such, $2 \mathrm{pmol} \cdot \mathrm{L}^{-1} \times 288.42$ $=576.84 \mathrm{pg} \cdot \mathrm{L}^{-1} \cdot 1 \mathrm{~L}=1000 \mathrm{~mL}$, so $576.84 \mathrm{pg} \cdot \mathrm{L}^{-1}=0.57 \mathrm{pg} \cdot \mathrm{ml}^{-1}$.

\begin{tabular}{lll} 
Conventional Units & & SI Units \\
$0.29 \mathrm{pg} \cdot \mathrm{ml}^{-1}$ & $\leftrightarrow$ & $1 \mathrm{pmol} \cdot \mathrm{L}^{-1}$ \\
$0.57 \mathrm{pg} \cdot \mathrm{ml}^{-1}$ & $\leftrightarrow$ & $2 \mathrm{pmol} \cdot \mathrm{L}^{-1}$ \\
$1.44 \mathrm{pg} \cdot \mathrm{ml}^{-1}$ & $\leftrightarrow$ & $5 \mathrm{pmol} \cdot \mathrm{L}^{-1}$ \\
$2.88 \mathrm{pg} \cdot \mathrm{ml}^{-1}$ & $\leftrightarrow$ & $10 \mathrm{pmol} \cdot \mathrm{L}^{-1}$ \\
$14.42 \mathrm{pg} \cdot \mathrm{ml}^{-1}$ & $\leftrightarrow$ & $50 \mathrm{pmol} \cdot \mathrm{L}^{-1}$ \\
$28.84 \mathrm{pg} \cdot \mathrm{ml}$ & $\leftrightarrow$ & $100 \mathrm{pmol} \cdot \mathrm{L}^{-1}$ \\
$57.69 \mathrm{pg} \cdot \mathrm{ml}^{-1}$ & $\leftrightarrow$ & $200 \mathrm{pmol} \cdot \mathrm{L}^{-1}$ \\
$144.21 \mathrm{pg} \cdot \mathrm{ml}^{-1}$ & $\leftrightarrow$ & $500 \mathrm{pmol} \cdot \mathrm{L}^{-1}$ \\
$288.42 \mathrm{pg} \cdot \mathrm{ml}^{-1}$ & $\leftrightarrow$ & $1000 \mathrm{pmol} \cdot \mathrm{L}^{-1}$ \\
$432.63 \mathrm{pg} \cdot \mathrm{ml}^{-1}$ & $\leftrightarrow$ & $1500 \mathrm{pmol} \cdot \mathrm{L}^{-1}$ \\
$576.84 \mathrm{pg} \cdot \mathrm{ml}^{-1}$ & $\leftrightarrow$ & $2000 \mathrm{pmol} \cdot \mathrm{L}^{-1}$ \\
\hline
\end{tabular}

Table 3 Conversion between commonly used units for salivary cortisol within physiologically observed ranges. The molecular mass of cortisol is $362.46 \mathrm{~g} \cdot \mathrm{mol}^{-1}$ and therefore $1 \mathrm{~mol}=362.46 \mathrm{~g}$. As such, $2 \mathrm{nmol} \cdot \mathrm{L}^{-1} \times 362.46$ $=724.92 \mathrm{ng} \cdot \mathrm{L}^{-1} \cdot 1 \mathrm{~L}=10 \mathrm{dl}$, so $724.92 \mathrm{ng} \cdot \mathrm{L}^{-1}=72.5 \mathrm{ng} \cdot \mathrm{dl}^{-1}$.

\begin{tabular}{|lll|}
\hline Conventional Units & & SI Units \\
\hline $36.2 \mathrm{ug} \cdot \mathrm{dl}^{-1}$ & $\leftrightarrow$ & $1 \mathrm{nmol} \cdot \mathrm{L}^{-1}$ \\
$72.5 \mathrm{ug} \cdot \mathrm{dl}^{-1}$ & $\leftrightarrow$ & $2 \mathrm{nmol} \cdot \mathrm{L}^{-1}$ \\
\hline $108.7 \mathrm{ug} \cdot \mathrm{dl}^{-1}$ & $\leftrightarrow$ & $3 \mathrm{nmol} \cdot \mathrm{L}^{-1}$ \\
\hline $145.0 \mathrm{ug} \cdot \mathrm{dl}^{-1}$ & $\leftrightarrow$ & $4 \mathrm{nmol} \cdot \mathrm{L}^{-1}$ \\
$181.2 \mathrm{ug} \cdot \mathrm{dl}^{-1}$ & $\leftrightarrow$ & $5 \mathrm{nmol} \cdot \mathrm{L}^{-1}$ \\
$362.5 \mathrm{ug} \cdot \mathrm{dl}^{-1}$ & $\leftrightarrow$ & $10 \mathrm{nmol} \cdot \mathrm{L}^{-1}$ \\
\hline $543.7 \mathrm{ug} \cdot \mathrm{dl}^{-1}$ & $\leftrightarrow$ & $15 \mathrm{nmol} \cdot \mathrm{L}^{-1}$ \\
$725.0 \mathrm{ug} \cdot \mathrm{dl}^{-1}$ & $\leftrightarrow$ & $20 \mathrm{nmol} \cdot \mathrm{L}^{-1}$ \\
\hline
\end{tabular}

obtain $\mathrm{T}$ and $\mathrm{C}$ measurement from saliva samples. Due to the significant heterogeneity of study design in studies that examine behavioral or psychological stimuli, this article is restricted to studies involving physiological outcome measures. However, the proposed guidelines can be applied across all studies using single or serial salivary hormone measurements.

\section{A: Study Design \\ $\nabla$}

A recent meta-analysis concerning exercise-induced sal-T and sal-C reactivity to acute exercise identified that effect sizes were dependent upon study design [69]. For example, pooled analysis of power exercise interventions that collected their baseline sample on a control day exhibited a negative $(-1.128)$ standard difference in means (SDM), whereas investigations that collected their baseline sample immediately prior to exercise exhibited a positive SDM (0.486) [69], meaning that study design is a confounding factor in salivary hormone determination. Here we have discussed causes of some of the limitations to appropriate design and interpretation of investigations, and how these may be improved in an applied research environment.

\section{Study title}

Whilst the majority of studies correctly report the use of salivary hormone methodology within titles, this is not always the case $[29,30,92]$. It has been suggested that sal-T and sal-C ostensibly measure the free fraction of the hormone [118] which is considered to diffuse passively across the salivary glands [122]. Khan-Dawood [86] reported free testosterone (free-T) to account for $78 \%$ of sal-T, compared with approximately $4 \%$ of TT in adult plasma, although the variability around this value is yet to be determined. Furthermore, 'free testosterone' is traditionally interpreted as the unbound component of serum concentrations. However, despite these issues a number of authors describe sal-T as 'free testosterone' $[36,38]$ within study titles. Such descriptions are both confusing and premature, at least until studies using gold-standard ultrafiltration measures of serum $\mathrm{T}$ confirm the T:sal-T ratio and the reliability of sal-T to reflect serum derived free-T [53]. Therefore, in the interest of good practice, we believe it necessary to state 'salivary' in the title of research articles for clarity and indexing purposes, and throughout manuscripts for transparency.

\section{Study design}

A recent meta-analysis of randomized control trials (RCTs) and uncontrolled trials (UCTs) resulted in different magnitudes of sal-T and sal-C response to exercise [69]. It was suggested that the anticipatory rise (or fall) prior to exercise was the underlying mechanism for this outcome. To further elucidate this point, two investigations that collected baseline samples on a rest day observed a relative decrease in sal-T following a power-based exercise intervention $[48,105]$, whereas several other studies that collected a sample immediately prior to exercise observed an increase in sal-T $[141,152]$. Without comparison to a control condition, it is difficult to discern the true effect of an intervention on sal-T and sal-C. Therefore, we recommend utilizing an RCT design where possible. Furthermore, if RCT designs are not feasible, and where participant data is to be compared with their own baseline data, the timing of salivary sampling becomes of paramount importance.

\section{Timing of pre- and post-intervention samples}

Since the first account of salivary hormone collection around the time of exercise [32], an anticipatory effect of the forthcoming activity has been observed. Cook and colleagues [32] reported increased sal-C and sal-T prior to a marathon run when compared to rest days. Therefore, we suggest that baseline samples are collected on a control day (without the anticipatory effect of intervention), as well as immediately pre-intervention, to elucidate the true effect of; A) the anticipatory effect on sal-T and sal-C compared to a control day, B) the intervention effect on sal-T and sal-C compared to pre-intervention, and $\mathrm{C}$ ) the combined effect of anticipation and intervention on sal-T and sal-C. With regards to post-intervention sample timing, Crewther et al. [34] observed a negative sal-T response immediately after completion of an exercise intervention, which when reassessed $15 \mathrm{~min}$ later, resulted in a positive change from baseline. We therefore propose post-intervention samples are taken between 15-30 min post-intervention as sal-T has been shown to peak $15 \mathrm{~min}$ post- exercise intervention and return to baseline values $30 \mathrm{~min}$ post-exercise [153].

\section{Data reporting}

There are a number of issues in data reporting which, if standardized, should improve the field of salivary hormone research. For example, reporting raw mean data in combination with either standard deviation (SD), standard error of the mean (SEM) or confidence intervals $(\mathrm{CI})$ rather than percentage change from baseline would add value and clarity to the data. Although reporting delta changes may be useful to contextualize findings, it may underestimate the absolute change in individuals with 
high baseline values. For example, an individual whose sal-T rises from 300 to $400 \mathrm{pmol} \cdot \mathrm{L}^{-1}$ following intervention experiences an absolute increase of $100 \mathrm{pmol} \cdot \mathrm{L}^{-1}$ and relative change of $33 \%$ yet an individual whose sal-T rises from 200 to $280 \mathrm{pmol} \cdot \mathrm{L}^{-1}$ following intervention experiences an absolute increase of $80 \mathrm{pmol} \cdot \mathrm{L}^{-1}$ but a relative change of $40 \%$. We therefore suggest reporting mean $\pm \mathrm{SD} / \mathrm{SE}$ as a standard minimum. Relative changes may be reported, to further contextualise findings in relation to a minimum meaningful change from baseline [91]. Regarding the minimum meaningful change, it may be useful to refer to the critical difference of sa-T and sal-C to determine whether changes observed are biologically meaningful $[79,145]$. This can be conducted for interventions within [79], or between days [145]. Furthermore, authors should adhere to the Système International d'Unités (SI Units) when reporting concentrations of sal-T and sal-C for continuity ( $\odot$ Table 2-3). Currently, a mix between $\mathrm{pmol} \cdot \mathrm{L}^{-1}$ and $\mathrm{pg} \cdot \mathrm{ml}^{-1}$ is used for sal-T whilst a mix between $\mathrm{nmol} \cdot \mathrm{L}^{-1}$ and $\mathrm{ug} \cdot \mathrm{dl}^{-1}$ is used for sal-C.

\section{Strength of evidence and recommendations}

There is considerable evidence that identifies study design and timing of pre- and post-intervention sample to adversely influence study outcomes from sal-T and sal-C research. Furthermore, discrepancies in data reporting and terminology compound inconsistencies within the literature.

\section{B: Sample Acquisition and Biological Variation} $\nabla$

Variability of sal-T and sal-C have been previously reported [70,79,137,145]. Recent evidence has described wide variation in the measurement of sal-T and sal-C within a highly controlled laboratory environment [79]. Therefore, in research outside of a laboratory, variability of sal-T and sal-C will likely be greater. In this section we discuss causes of some of the major sources of biological variation and how these may be controlled in an applied research environment.

\section{Chronobiological variation}

Circadian rhythmicity has been established in serum C [129] and $\mathrm{T}[97,156]$, as well as in sal-C $[111,112]$ and sal-T $[70,90,139]$. As a result of these diurnal variations, it is imperative to employ similar sampling times during repeated measures research design. Furthermore, in prospective cohort studies where a baseline measure will be used as control data (i.e., without a control group), it may be difficult to determine true sal-T and sal- $C$ response to exercise if the exercise intervention is protracted. For example, if examining sal-T and sal- $\mathrm{C}$ response to a marathon run, recreational athletes would take $>3 \mathrm{~h}$ to complete the course. If using a baseline-as-control design, it would prove difficult to determine whether hormone alterations observed were a result of running, or simply a product of chronological advancement. Therefore, we suggest the use of dual baseline sampling for protracted interventions. i.e., Samples should be collected pre-intervention, and time-matched post-intervention on a control day to eliminate the effect of diurnal variation.

\section{Chronological age}

Longitudinal analysis has revealed that for each decade from the age of 30 years there is a downward trend of TT [67]. This precipitous decline, coupled with increasing SHBG with age, further reduces bioavailable testosterone (bio-T) $[7,13,17]$, thought to constitute the majority of sal-T. Morley and colleagues [109] reported sal-T in 1454 males, with mean basal sal-T ranging from $\sim 100 \mathrm{pg} \cdot \mathrm{ml}^{-1}\left(347 \mathrm{pmol} \cdot \mathrm{L}^{-1}\right)$ to $\sim 50 \mathrm{pg} \cdot \mathrm{ml}^{-1}\left(173 \mathrm{pmol} \cdot \mathrm{L}^{-1}\right)$ for ages 30-39 and 80-89 respectively. Recently, we have observed that sal-T demonstrated poor agreement with TT and calculated bio-T and free-T in older men [76,77]. Additionally, older males are more likely to exhibit hypogonadism [67], yet sal-T is incapable of diagnosing hypogonadism $[53,78]$. Although older males have lower resting sal-T, they may have the potential to increase sal-T to a greater relative extent following exercise [22] further supporting the need to report absolute as well as relative changes suggested earlier. However, more data are required to confirm this phenomenon. Whilst TT decreases with age, a coincident age-related increase in TC [157] and sal-C [21] occur which would therefore lower the T:C ratio, more so in saliva, where SHBG further compromises this relationship. However, this is yet unconfirmed. It is therefore suggested that between group designs are closely age-matched. Moreover, a narrow spread of ages is suggested to prevent large standard deviation in absolute and delta change values.

\section{Sex}

Until the onset of puberty, males and females exhibit little difference in their resting hormonal profiles. Once puberty is reached, females demonstrate the characteristic pulsatile release of gonatrotrophin and sex steroid hormones throughout menarch and males demonstrate increased androgen steroid hormone production [149]. Differences that manifest at puberty tend to persist through adulthood until women become postmenopausal [63]. Moreover, gender specific syndromes may further increase biological variation. For example, incidence of hypogonadism (clinically low $\mathrm{T}[6,109]$ ) would increase biological variation within a participant sample, with incidence possibly elevated in athletes $[42,43,132]$. Polycystic ovary syndrome (PCOS) increases TT [83], and sal-T [138] in females and would therefore confound direct comparisons between symptomatic and asymptomatic females. It is also well reported that differences between men and women exist for both sal-T and sal-C $[86,121,151]$. We therefore suggest that mixed gender experiments should be avoided where possible as large standard deviation may increase type II error risk. Gender specific syndromes which may influence androgen status (hypogonadism, PCOS, etc.) should, where possible, be screened for in order to prevent confounding results further.

\section{Long haul travel}

Long haul travel across multiple time zones causes a depression in sal-C the day following travel [18]. Whilst there is no information from sal-T data, data from serum indicate that after a simulated long-haul flight, TT circadian rhythm was not altered [33]. However, simulation of hypoxia and hypobaria was $12000 \mathrm{ft}$, whereas commercial airplanes fly at over $30000 \mathrm{ft}$. In addition, as a result of circadian disruption due to crossing multiple time zones, long haul travel may influence serum TC and TT release. Therefore, recent long haul travel should be used as exclusion criteria where possible when obtaining sal-T and sal-C measurements.

\section{Dietary intake}

There are a wide variety of dietary factors that have been shown to influence sal-T and sal-C. Consuming an evening meal causes an increase in sal-T compared to fasting [143], whilst 3 weeks of daytime fasting, reduces sal-C [146]. High alcohol consumption 
[110], low zinc intake [2], and a low carbohydrate diet [4] all decrease TT. Volek and colleagues [148] have demonstrated that the relative contribution to energy intake from protein, fat, saturated fatty acids, monounsaturated fatty acids, the polyunsaturated fat-to-saturated fat ratio, and the protein-to-carbohydrate ratio influenced TT but not TC concentrations, using a 17-day dietary recall. Heikkonen and coworkers [80] reported that alcohol consumption depressed TT, but increased TC concentrations. Controlling for diet may further reduce biological error in sal-T and sal-C research. This can be achieved by providing standardised meals. Dietary recall may be more cost-effective, if the known problems with dietary recall in children [107] and adults [54] can be reconciled.

\section{Postural changes}

Changes in plasma volume with movement between supine and standing positions are now well established though sometimes overlooked. Movement from an initial standing position to a supine position has demonstrated significant haemodilution $[64,140]$ although a method for plasma volume correction has been outlined by Dill and Costill [44]. Failing to standardize body position or failing to correct for any changes in plasma volume increases error and has important interpretative implications [52]. In cases where plasma hormones are measured, correcting for plasma volume changes becomes an important consideration. Sal-C has been shown to increase following $20 \mathrm{~min}$ of standing, compared to sitting and lying [81]. Hucklebridge et al. [84] proposed the orthostatic challenge, adjusting from sitting to standing, stimulated the hypothalamic-pituitary-adrenal (HPA) axis as a result of hypotension, increasing sal-C. However, these same authors [84] observed no alteration in the sal-C awakening response when participants remained supine for $45 \mathrm{~min}$ or standing immediately upon wakening. Whilst no articles exist to our knowledge, concerning postural change and salT, hydration status [100], and salivary flow rate [6] did not influence sal-T concentrations. However, this area requires further confirmatory data as few studies exist addressing postural change and salivary hormone concentrations, particularly sal-T. As there are few data to confirm the influence postural change has on salivary hormones, we propose that repeated measures designs utilize the same posture for sampling at all sampling points, and we advise samples are collected seated or supine.

\section{Acute and habitual physical activity}

Exercise has been shown to increase levels of sal-T and sal-C acutely and chronically $[19,31,38,120,147]$, however there is some controversy surrounding chronic elevations in TT [99]; as some reports suggest depressed TT levels as a result of chronic endurance training [8]. The adaptation of the HPA axis to training is mediated by decreased sensitivity to TC $[45,95]$ and altered tissue sensitivity to glucocorticoids $[46,47]$. However, during a rest day, endurance athletes' serum TC concentrations have been reported as normal [47]. As the $\mathrm{T}: \mathrm{C}$ ratio has been implicated as a marker of overtraining and training status $[3,102]$, prior physical activity may influence findings of sal-T and sal-C investigations when examining individuals with a high training volume. It is common practice to exclude physical activity for $24 \mathrm{~h}$ prior to study commencement, which is preferential. However, in an applied setting, athletes may not have $24 \mathrm{~h}$ without training. In these instances, duration, and programme variables of last training session should be matched for repeated-measures designs.

\section{Smoking}

Basally, smokers demonstrate altered sal-T and sal-C compared to controls $[9,106,155]$. Furthermore, English and colleagues [49] reported elevated levels of total, free, and bioavailable $T$ in smokers compared with non-smokers. Cigarette smoking is further associated with acutely elevated TC levels. However, the results of TC comparison in smokers and non-smokers have been inconsistent, and the significance of TC responses in smoking cessation is unclear $[136,144]$. Therefore, for precaution, we advise smoking status to be used as exclusion criteria when not considered the independent variable.

\section{Sexual activity}

Mohammed [41] reported that, in both males and females, sal-T increased during an evening when there was intercourse and decreased when there was not. Moreover, sal-T has been shown to increase during a visit to a sex club in men [50], but no increase in sal-T or sal-C was observed following sexual thoughts [58]. Sexual activity influences TT concentrations in males and females [119]. Dabbs and Hamilton [65] demonstrated TC response to sexual arousal was highly individualized in females and Exton et al. [51] reported no significant influence of sexual arousal of TC levels in males. We are unaware of any studies to date that report the influence of sexual activity on sal-C or sal-T response to intervention. As such, abstinence should be requested $24 \mathrm{hr}$ prior to salivary collection, similar to alcohol, and physical activity.

\section{Illness}

Shattuck and colleagues [130] reported reduced sal-T in response to immune activation. Critical illness is often accompanied by hypercortisolemia, which has been attributed to stress-induced activation of the HPA axis, observed in both sera and saliva [115]. However, low corticotropin levels have been reported in critically ill patients, which may be due to reduced TC metabolism [15]. In men, serum TT decreases during sepsis, burns, myocardial infarction, and surgery [133-135]. Spratt and colleagues [134] reported patients admitted to critical care units displayed decreased TT that varied according to severity of illness. We are unaware of any study to date that evaluates the influence of lowgrade illness (i.e., cold or flu) on sal-C or sal-T. This is likely due to difficulty recruiting and opportunity of sampling yet this may be an area for further exploration. Illness should be controlled for during sal-T and sal-C research to the best of researchers' abilities (i.e., pre-participation questionnaire or verbal screening).

\section{Psychological influence}

Cortisol is the primary stress hormone and therefore is elevated in physiologically and psychologically stressful situations [126]. An increasing number of psychophysiology studies use sal-T and sal-C to reflect differences or changes in mood state $[20,113,158]$, though there are a number of contradictory overlaps and methodological issues [74,75]. Bernhardt and colleagues [12] investigated the sal-T response of football fans watching their teams win or lose. The study found that elation the winning team's fans felt was accompanied by a rise in post-game sal-T levels compared to pre-game. The despondency felt by the losing team's fans was accompanied by a decrease in sal-T. Increased sal-T in response to, or anticipation of, competition and sports performance has previously been observed [127]. This phenomenon has also been observed in the non-physical competition of chess $[16,68]$, reporting increased pre-competition sal-T in eventual 
winners. Territorial aggression of home teams is also well documented [5] linked to agonistic animalistic behavior defending a home territory [113].

Chronic stress can decrease TT $[1,104]$. It has been suggested that the suppression of steroidogenesis in the testes is due to reduced synthesis of testicular androgens, caused by the inhibitory effect of high adrenocorticotropic hormone (ACTH) levels that accompany chronic stress [24]. Conversely, acute stress can increase TT [123], which may be a consequence of increased sensitivity to LH [24] which is supported by documented sympathetic stimulation by catecholamine release in males and females [26,27]. The use of saliva sampling as opposed to venous blood draws may reduce stress in some instances. However, familiarization with passive drool is still advised to avoid apprehension. Fingerprick sampling and capillary tubes may be a viable alternative due to the relatively small volume of serum required for analysis and therefore less apprehension than during venous blood collection. Capillary TC accurately reflects samples from venous blood [55], yet further investigation is required as to whether this is a viable technique for testosterone measurement.

An often cited relationship exists between $\mathrm{T}$ and aggression, which is further demonstrated by the reported increased aggression or 'roid-rage' following consumption of supraphysiological dose $\mathrm{T}$ in anabolic androgenic steroid users (AAS). However, in individuals within normal physiological ranges of TT, only a weak positive relationship between TT and aggression exists in humans [5]. We propose that aggressive or stressful stimuli should be used as inclusion/exclusion criteria, preceding saliva collection. Where this may not be possible, practitioners may wish to control for stress by administering a stress questionnaire. E.g., perceived stress questionnaire (PSQ) [89].

\section{Ethnographical differences}

Martin et al. [101] described racial differences in diurnal sal-C rhythms whereby African Americans exhibited dampened morning-to-evening sal-C slopes than Caucasions. Christiansen [25] observed that sal-T from men in !Kung San was lower in comparison to published normal mean values. Panizzon et al. [116] described significant heritability in sal-T measures ( 0.42 and $\sim 0.47$ for at-home and in-lab values respectively). Serum TT levels are higher in adult male Bangladeshi migrants to the United Kingdom compared to residents of Bangladesh [108], and in native Anymara men in urban vs. rural Bolivia [10], as well as Chinese men living in Pennsylvania vs. Beijing [128]. However, this may be as a consequence of dietary intake. Winter and colleagues [154] have reported higher TT concentrations in African-American men compared to Caucasian men, whereas Litman and coworkers [98] observed no such difference. Therefore, in between-group investigations, it may be useful to control for ethnic differences or at least acknowledge the influence ethnicity or geographical location may exert.

\section{Strength of evidence and recommendations}

In summary, a number of our recommendations are based on serum data, which we have extrapolated to the determination of salivary hormones. This in itself is problematic due to some authors reporting weak, or no relationships between salivary and serum values $[61,76,78,87,131]$. There is however, evidence that chronological variation, chronological age, sex, dietary intake, acute and habitual physical activity, smoking, illness, mood state and psychology, and geographical differences influ- ence sal-T and sal-C. Conversely, whilst there is evidence of long haul travel influencing sal-C, currently there is no investigation to our knowledge concerning the influence of travel on sal-T. Whilst TT was reportedly unaltered following hypoxic hypobaria, conditions investigated did not closely match those of long haul flights and thus we cannot declare for certain whether sal-T is influenced by long haul travel. Sal-C has been shown to vary following postural change. However, there are no data addressing postural changes and sal-T. Extrapolating from serum data, Hoffman and colleagues [82] observed no change in TT following reduced plasma volume and therefore sal-T may remain unchanged. However, this is purely speculation until further confirmatory data.

\section{C: Technical and Analytical Error \\ $\nabla$}

As previously described [79], the critical difference includes both biological error, and technical and analytical error. As with the biological error discussed above, steps should be taken to minimize the technical and analytical error when assessing samples. Lazarou and colleagues [94] reported that in a study examining reference values for hypogonadism in 25 laboratories, there were 17 different threshold values for TT. Indeed, the threshold for hypogonadism diagnosis varied by $350 \%$ ( $130 \mathrm{ng} \cdot \mathrm{dl}^{-1}$ to $450 \mathrm{ng} \cdot \mathrm{dl}^{-1}$ ). Whilst there is some discrepancy concerning clinical thresholds in serum testosterone, the innate variability of sal-T means it is unsuitable for clinical diagnosis $[53,78]$. To exemplify this point, Jensen et al. [85] compared analysis of sal-T and sal-C samples amongst 4 and 3 laboratories respectively. These authors reported recovery of spiked material for testosterone and cortisol was $80-94 \%$ and $83-100 \%$ respectively. Moreover, substantial differences existed between laboratories, as a result of traceability, clean-up procedures, or issues with calibration Crewther and colleagues [37] reported power trained males had mean basal sal-T concentrations of $107 \mathrm{pg} \cdot \mathrm{ml}^{-1}\left(371 \mathrm{pmol} \cdot \mathrm{L}^{-1}\right)$ whereas Ghigiarelli et al. [57] reported basal levels of as high as $180 \mathrm{pg} \cdot \mathrm{ml}^{-1}\left(624 \mathrm{pmol} \cdot \mathrm{L}^{-1}\right)$. In a multicentre study [40], mean sal-T concentrations from the same 100 males ranged from $240 \pm 95$ to $410 \pm 191 \mathrm{pmol} \cdot \mathrm{L}^{-1}$ $\left(69-118 \mathrm{pg} \cdot \mathrm{ml}^{-1}\right)$ suggesting considerable heterogeneity between laboratories. Fiers et al. [53] recently provided evidence for T binding to salivary proteins, therefore limiting the agreement with free-T in serum, determined by equilibrium dialysis. These taken together, suggest large variability in sal-T, so precautions are needed in order to reduce sampling error. In this section, we detail some of the major analytical variation and provide advice for researchers using sal-T and sal-C.

\section{Collection method}

Flavored beverage crystals and lemon juice have been used to stimulate flow of saliva. Flavored crystals may cause an increase in measured sal-C concentrations whereas lemon juice may compromise sal-C determination as a result of decreased $\mathrm{pH}$ [59]. With regards to sample acquisition, Granger et al. [61] observed chewing sugar free dental gum resulted in increased sal-T levels after $1 \mathrm{~min}$ (mean $168 \mathrm{pmol} \cdot \mathrm{L}^{-1}, \mathrm{SEM}=58 \mathrm{pmol} \cdot \mathrm{L}^{-1}$ compared to $138 \mathrm{pmol} \cdot \mathrm{L}^{-1}, \mathrm{SEM}=53 \mathrm{pmol} \cdot \mathrm{L}^{-1}$ ) but thereafter no significant differences were observed. Granger et al. [61] investigated the effects of different sample collection techniques on the measurement of sal-T. In this study, sal-T collected using cotton dental roll, cotton swab and sugar free gum were com- 
pared to un-stimulated saliva collection. Compared to un-stimulated saliva (mean $=10.1 \mathrm{gg} \cdot \mathrm{ml}^{-1}\left[34.9 \mathrm{pmol} \cdot \mathrm{L}^{-1}\right]$ ), sal-T levels were 2 fold higher $\left(\right.$ mean $\left.=20.7 \mathrm{pg} \cdot \mathrm{ml}^{-1}\left[71.4 \mathrm{pmol} \cdot \mathrm{L}^{-1}\right]\right)$ using dental cotton roll, and almost 3fold higher $\left(28.3 \mathrm{pg} \cdot \mathrm{ml}^{-1}\right.$ [98.1 $\left.\mathrm{pmol} \cdot \mathrm{L}^{-1}\right]$ ) after using a cotton swab. Moreover, Shirtcliff and coworkers [131] reported compromised assay results when using cotton materials to absorb saliva. It was shown that the cotton interference effect was of sufficient magnitude to attenuate the association between serum and saliva levels. Therefore, unstimulated, mid-flow saliva is recommended for analysis. It may also be advised to wash out the mouth with distilled water approximately $10 \mathrm{~min}$ before sample collection to clear the oral cavity of debris.

\section{Blood contamination}

Hormones in saliva are present at far lower concentrations than in circulation. As a result, blood leakage into the oral mucosa can compromise the validity of salivary hormone analysis $[61,88]$. Blood contamination may be caused by teeth brushing, drinking hot fluid, or the use of swabs for sample collection [96]. Blood can leak into saliva as a result of micro-injuries such as burns, cuts or abrasions or gum disease/poor oral hygiene. In sport, both the abrasion to the gums from the use of gum shields and facial injuries can lead to the presence of blood in saliva. Kivlighan et al. [88] investigated the effect of blood leakage on sal-T and sal-C concentrations. Saliva samples were taken before, immediately after, and every $15 \mathrm{~min}$ for $1 \mathrm{~h}$ following vigorous tooth brushing and the same protocol without tooth brushing was performed by a control group. There was a significant increase in sal-T at 15,30 and 45 min post micro-injury compared to control. Paradoxically, there was no difference in sal-C levels between the micro-injury and the control condition. This suggests that sal-C is unaffected by blood contamination in saliva although given the appreciable concentration gradient between serum and saliva $C$, this requires further investigation. Whilst few studies report the acceptable transferrin level in saliva, this could be used as exclusion criteria $[39,88]$. We propose that investigators ensure avoidance of hot food and drinks, and teeth brushing prior to sample collection. Furthermore, we suggest that following gum shield use, samples are visually inspected for blood contamination and then leakage confirmed by transferring analysis.

\section{Storage}

Steroid hormones such as $C$ have generally been considered to be stable in saliva even when stored at room temperature for a number of days $[23,56]$. However, more recent studies have raised concern with respect to sample treatment and storage prior to analysis $[61,117,142]$. Concentrations of sal-C were found to decrease by $9.2 \%$ per month in samples stored at room temperature [56] compared to baseline. Toone et al. [142] observed that following 7 days of storage at $4^{\circ} \mathrm{C}$, sal-T decreased by $26 \pm 15 \%$ whereas sal-C remained unchained compared to baseline.

With regard to storing saliva samples, 2 freezing options are generally used. Saliva can be stored for a year in a domestic freezer $\left(-20^{\circ} \mathrm{C}\right)$, and possibly several years in a laboratory-based freezer $\left(-80^{\circ} \mathrm{C}[66]\right)$. After collection, saliva should be frozen as soon as possible [117] to precipitate mucins; however if unavailable, saliva can be stored at room temperature for up to $6 \mathrm{~h} \mathrm{[66].}$ Storing saliva at $>-5^{\circ} \mathrm{C}$ will not freeze the samples and is not generally recommended due to bacterial growth which may degrade salivary components and interfere with antibody binding [61]. Granger et al. [61] analyzed saliva samples stored at $4^{\circ} \mathrm{C}$ which were assayed for sal-T on a weekly basis for 4 consecutive weeks. Contradictory to the data of Toone et al. [142], measured sal-T levels increased by $20.6 \%$ after one week and $330.8 \%$ after 4 weeks compared to baseline. Therefore, we recommend studies freeze salivary samples as quickly as possible in a freezer as cold as possible. $-80^{\circ} \mathrm{C}$ is preferred but $-20^{\circ} \mathrm{C}$ is suitable as long as samples are analyzed within 12 months.

\section{Analysis}

Numerous techniques have been used to measure sal-C and sal-T concentrations, including enzyme-linked immunosorbent assay (ELISA), radioimmunoassay (RIA), and liquid chromatographytandem mass spectrometry (LC-MS/MS). Analytical sensitivity differs between these methods, as discussed elsewhere $[53,124]$. Despite the ease and speed of analysis compared to LC-MS/MS, results from ELISA and RIA are generally considered less accurate, possibly due to the lack of consistent reference standards. More recently, handheld detection devices have come to market offering salivary hormone determination [28]. However, whilst there are conference proceedings suggesting acceptable reliability and validity of these devices, no full text articles exist to date confirming suitability of sal-T and sal-C values using this method.

Variability of serum thresholds varies between laboratories [94], and possibly as a result, reference ranges for sal-T have not been agreed to date. As such, sal-T and sal-C assays are limited to interpretation by identifying 'outliers' within a group/team and/ or comparison with previously determined measure. In an attempt to minimize error through analytical procedure, we suggest LC-MS/MS be used where possible. When this is not viable, due to the innate laborious methodology, it is imperative all analysis is conducted in the same laboratory, by the same investigator, in duplicate or triplicate. We also advise that direct comparisons are made only with findings from the same methodological technique. Coefficient of variation needs to be reported in all cases.

\section{Strength of evidence and recommendations}

In summary, there is evidence that sal-T and sal-C is directly influenced by collection method, blood contamination, storage duration and temperature, and analysis method. Whilst saliva collection has obvious advantages over blood, accuracy, variability, and salivary protein binding may limit interpretation of results. As capillary sampling has been validated for analysis of TC, this may be an option for TT determination, however this currently requires validation.

\section{Conclusion}

\section{$\nabla$}

Salivary analysis of $\mathrm{C}$ and $\mathrm{T}$ in sports people will soon enter its fourth decade as a research tool. The benefits of this method are well documented and primarily focus on ease of sample and subsequent analysis. However, there is a general lack of consistency between studies that use salivary measures of $\mathrm{T}$ and $\mathrm{C}$ as surrogates for their systemic counterparts. These include issues related to A) study design, B) sample acquisition and biological variation, and C) technical and analytical error. We would 
encourage researchers to consider each of A, B, and C, as outlined above in the formulation of study design, participant information sheets, and in their reporting of study outcomes.

\section{Affiliations}

${ }^{1}$ Department of Medical and Sport Sciences, University of Cumbria, Lancaster, United Kingdom of Great Britain and Northern Ireland ${ }^{2}$ Institute of Clinical Exercise and Health Science, University of the West of Scotland, Hamilton, United Kingdom of Great Britain and Northern Ireland ${ }^{3}$ English Institute of Sport, English Institute of Sport, Marlow,

United Kingdom of Great Britain and Northern Ireland

${ }^{4}$ Faculty of Health, Federation University, Victoria, Australia

\section{References}

1 Aakvaag A, Sand T, Opstad PK, Fonnum F. Hormonal changes in serum in young men during prolonged physical strain. Eur J Appl Physiol 1978; 39: 283-291

2 Abbasi AA, Prasad AS, Rabbani P, DuMouchelle E. Experimental zinc deficiency in man. Effect on testicular function. J Lab Clin Med 1980; 96: $544-550$

3 Adlercreutz H, Harkonen M, Kuoppasalmi K, Naveri H, Huhtaniemi I, Tikkanen $H$, Remes $K$, Dessypris A, Karvonen J. Effect of training on plasma anabolic and catabolic steroid-hormones and their response during physical exercise. Int J Sports Med 1986; 7: 27-28

4 Anderson KE, Rosner W, Khan MS, New MI, Pang S, Wissel PS, Kappas A. Diet-hormone interactions - protein carbohydrate ratio alters reciprocally the plasma-levels of testosterone and cortisol and their respective binding globulins in man. Life Sci 1987; 40: 1761-1768

5 Archer J. The influence of testosterone on human aggression. $\mathrm{Br} J$ Psychol 1991; 82 (Pt 1): 1-28

6 Arregger AL, Contreras LN, Tumilasci OR, Aquilano DR, Cardoso EM. Salivary testosterone: a reliable approach to the diagnosis of male hypogonadism. Clin Endocrinol 2007; 67: 656-662

7 Atlantis E, Martin SA, Haren MT, O'Loughlin PD, Taylor AW, Anand-Ivell $R$, Ivell $R$, Wittert GA. Demographic, physical and lifestyle factors associated with androgen status: the Florey Adelaide Male Ageing Study (FAMAS). Clin Endocrinol 2009; 71: 261-272

8 Bagatell CJ, Bremner WJ. Sperm counts and reproductive hormones in male marathoners and lean controls. Fertil Steril 1990; 53: 688-692

9 Bauman KE, Foshee VA, Koch GG, Haley NJ, Downton MI. Testosterone and cigarette smoking in early adolescence. J Behav Med 1989; 12: 425-433

10 Beall CM, Worthman CM, Stallings J, Strohl KP, Brittenham GM, Barragan $M$. Salivary testosterone concentration of Aymara men native to 3600 m. Ann Hum Biol 1992; 19: 67-78

11 Beaven CM, Cook C, Gray D, Downes P, Murphy I, Drawer S, Ingram JR, Kilduff LP, Gill N. Electrostimulation's Enhancement of Recovery During a Rugby Preseason. Int J Sports Physiol Perform 2013; 8: 92-98

12 Bernhardt PC, Dabbs JM Jr, Fielden JA, Lutter CD. Testosterone changes during vicarious experiences of winning and losing among fans at sporting events. Physiol Behav 1998; 65: 59-62

13 Bjerner J, Biernat D, Fossa SD, Bjoro T. Reference intervals for serum testosterone, SHBG, LH and FSH in males from the NORIP project. Scand J Clin Lab Invest 2009; 69: 873-879 e871-e811

14 Blair-West JR, Coghlan JP, Denton DA, Goding JR, Wright RD. The effect of aldosterone, cortisol, and corticosterone upon the sodium and potassium content of sheep's parotid saliva. J Clin Invest 1963; 42: 484-496

15 Boonen E, Vervenne H, Meersseman P, Andrew R, Mortier L, Declercq $P E$, Vanwijngaerden YM, Spriet I, Wouters PJ, Vander Perre S, Langouche L, Vanhorebeek I, Walker BR, Van den Berghe G. Reduced cortisol metabolism during critical illness. N Engl J Med 2013; 368: 14771488

16 Booth A, Mazur AC, Dabbs JM Jr. Endogenous testosterone and competition: the effect of "fasting". Steroids 1993; 58: 348-350

17 Brand JS, Wareham NJ, Dowsett M, Folkerd E, van der Schouw YT, Luben $R N$, Khaw K-T. Associations of endogenous testosterone and SHBG with glycated haemoglobin in middle-aged and older men. Clin Endocrinol 2011; 74: 572-578

18 Bullock N, Cox AJ, Martin DT, Marino FE. Resting salivary and plasma cortisol in elite athletes following long-haul travel from Australia to Canada. J Sci Med Sport 2009; 12: 300-302

19 Caruso JF, Lutz BM, Davidson ME, Wilson K, Crane CS, Craig CE, Nissen TE, Mason ML, Coday MA, Sheaff RJ, Potter WT. Salivary hormonal values from high-speed resistive exercise workouts. J Strength Cond Res 2012; 26: 625-632
20 Casanova N, Palmeira-de-Oliveira A, Pereira A, Crisostomo LD, Travassos $B$, Costa $A M$. Cortisol, testosterone and mood state variation during an official female football competition. J Sports Med Phys Fitness 2015 [Epub ahead of print]

21 Ceccato F, Barbot M, Zilio M, Ferasin S, De Lazzari P, Lizzul L, Boscaro $M$, Scaroni $C$. Age and the metabolic syndrome affect salivary cortisol rhythm: data from a community sample. Hormones 2015; 14: 392398

22 Chang CK, Tseng HF, Tan HF, Hsuuw YD, Lee-Hsieh J. Responses of saliva testosterone, cortisol, and testosterone-to-cortisol ratio to a triathlon in young and middle-aged males. Biol Sport 2005; 22: 227-235

23 Chen YM, Cintron NM, Whitson PA. Long-term storage of salivary cortisol samples at room temperature. Clin Chem 1992; 38: 304

24 Chichinadze K, Chichinadze N. Stress-induced increase of testosterone: contributions of social status and sympathetic reactivity. Physiol Behav 2008; 94: 595-603

25 Christiansen KH. Serum and saliva sex hormone levels in!Kung San men. Am J Phys Anthropol 1991; 86: 37-44

26 Chrousos GP. Ultradian, circadian, and stress-related hypothalamicpituitary-adrenal axis activity - a dynamic digital-to-analog modulation. Endocrinology 1998; 139: 437-440

27 Chrousos GP, Gold PW. A healthy body in a healthy mind - and vice versa - the damaging power of "uncontrollable" stress. J Clin Endocrinol Metab 1998; 83: 1842-1845

28 Coad S, McLellan C, Whitehouse T, Gray B. Validity and reliability of a novel salivary immunoassay for individual profiling in applied sports science. Res Sports Med 2015; 23: 140-150

29 Cook CJ, Crewther BT, Kilduff LP. Are free testosterone and cortisol concentrations associated with training motivation in elite male athletes? Psychol Sport Exerc 2013; 14: 882-885

30 Cook CJ, Crewther BT, Smith AA. Comparison of baseline free testosterone and cortisol concentrations between elite and non-elite female athletes. Am J Hum Biol 2012; 24: 856-858

31 Cook CJ, Kilduff LP, Beaven CM. Improving strength and power in trained athletes with 3 weeks of occlusion training. Int J Sports Physiol Perform 2014; 9: 166-172

32 Cook NJ, Read GF, Walker RF, Harris B, Riadfahmy D. Changes in adrenal and testicular activity monitored by salivary sampling in males throughout marathon runs. Eur J Appl Physiol 1986; 55: 634-638

33 Coste O, Van Beers P, Charbuy H, Bogdan A, Touitou Y. Simulation of long-haul flights in humans: prolonged mild hypoxia does not alter the circadian time structure of plasma testosterone and gonadotrophins. Steroids 2006; 71: 214-221

34 Crewther B, Cronin J, Keogh J, Cook C. The salivary testosterone and cortisol response to three loading schemes. J Strength Cond Res 2008; 22: 250-255

35 Crewther BT, Al-Dujaili E, Smail NF, Anastasova S, Kilduff LP, Cook CJ. Monitoring salivary testosterone and cortisol concentrations across an international sports competition: Data comparison using two enzyme immunoassays and two sample preparations. Clin Biochem 2013; 46: 354-358

36 Crewther BT, Cook CJ. Effects of different post-match recovery interventions on subsequent athlete hormonal state and game performance. Physiol Behav 2012; 106: 471-475

37 Crewther BT, Kilduff LP, Cook CJ, Cunningham DJ, Bunce P, Bracken RM, Gaviglio CM. Relationships between salivary free testosterone and the expression of force and power in elite athletes. J Sports Med Phys Fitness 2012; 52: 221-227

38 Crewther BT, Sanctuary CE, Kilduff LP, Carruthers JS, Gaviglio CM, Cook CJ. The workout responses of salivary-free testosterone and cortisol concentrations and their association with the subsequent competition outcomes in professional rugby league. J Strength Cond Res 2013; 27: 471-476

39 Cunniffe B, Morgan KA, Baker JS, Cardinale M, Davies B. 'Home Vs Away' Competition: Effect on Psychophysiological Variables in Elite Rugby Union. Int J Sports Physiol Perform 2015, [Epub ahead of print] doi:10.1123/ijspp.2014-0370

40 Dabbs JM Jr, Campbell BC, Gladue BA, Midgley AR, Navarro MA, Read GF, Susman EJ, Swinkels LM, Worthman CM. Reliability of salivary testosterone measurements: a multicenter evaluation. Clin Chem 1995; 41: 1581-1584

41 Dabbs JM Jr, Mohammed S. Male and female salivary testosterone concentrations before and after sexual activity. Physiol Behav 1992; 52: $195-197$

42 Di Luigi L, Romanelli F, Sgro P, Lenzi A. Andrological aspects of physical exercise and sport medicine. Endocrine 2012; 42: 278-284 
43 Di Luigi L, Sgro P, Fierro V, Bianchini S, Battistini G, Magini V, Jannini $E A$, Lenzi A. Prevalence of undiagnosed testosterone deficiency in aging athletes: does exercise training influence the symptoms of male hypogonadism? J Sex Med 2010; 7: 2591-2601

44 Dill $D B$, Costill DL. Calculation of percentage changes in volumes of blood, plasma, and red cells in dehydration. J Appl Physiol 1974; 37: 247-248

45 Duclos M, Corcuff JB, Arsac L, Moreau-Gaudry F, Rashedi M, Roger P, Tabarin A, Manier G. Corticotroph axis sensitivity after exercise in endurance-trained athletes. Clin Endocrinol 1998; 48: 493-501

46 Duclos M, Gouarne C, Bonnemaison D. Acute and chronic effects of exercise on tissue sensitivity to glucocorticoids. J Appl Physiol 2003; 94: 869-875

47 Duclos M, Minkhar M, Sarrieau A, Bonnemaison D, Manier G, Mormede $P$. Reversibility of endurance training-induced changes on glucocorticoid sensitivity of monocytes by an acute exercise. Clin Endocrinol 1999; 51: 749-756

48 Elloumi M, Maso F, Michaux O, Robert A, Lac G. Behaviour of saliva cortisol $\mathrm{C}$, testosterone $\mathrm{T}$ and the $\mathrm{T} / \mathrm{C}$ ratio during a rugby match and during the post-competition recovery days. Eur J Appl Physiol 2003; 90: $23-28$

49 English KM, Pugh PJ, Parry H, Scutt NE, Channer KS, Jones TH. Effect of cigarette smoking on levels of bioavailable testosterone in healthy men. Clin Sci 2001; 100: 661-665

50 Escasa MJ, Casey JF, Gray PB. Salivary testosterone levels in men at a U.S. sex club. Arch Sex Behav 2011; 40: 921-926

51 Exton NG, Truong TC, Exton MS, Wingenfeld SA, Leygraf $N$, Saller B, Hartmann $U$, Schedlowski $M$. Neuroendocrine response to filminduced sexual arousal in men and women. Psychoneuroendocrinology 2000; 25: 187-199

52 Fall L, Evans KA, Lewis MH, Bailey DM. Haemostatic response to hypoxaemic/exercise stress: the dilemma of plasma volume correction. J Clin Pathol 2011; 64: 269-271

53 Fiers T, Delanghe J, T'Sjoen G, Van Caenegem E, Wierckx K, Kaufman $J-M$. A critical evaluation of salivary testosterone as a method for the assessment of serum testosterone. Steroids 2014; 86: 5-9

54 Freedman LS, Commins JM, Moler JE, Willett W, Tinker LF, Subar AF, Spiegelman D, Rhodes D, Potischman N, Neuhouser ML, Moshfegh AJ, Kipnis V, Arab L, Prentice RL. Pooled results from 5 validation studies of dietary self-report instruments using recovery biomarkers for potassium and sodium intake. Am J Epidemiol 2015; 181: 473-487

55 Fryer SM, Dickson T, Hillier S, Stoner L, Scarrott C, Draper N. A comparison of capillary, venous, and salivary cortisol sampling after intense exercise. Int J Sports Physiol Perform 2014; 9: 973-977

56 Garde $A H$, Hansen AM. Long-term stability of salivary cortisol. Scand J Clin Lab Invest 2005; 65: 433-436

57 Ghigiarelli JJ, Sell KM, Raddock JM, Taveras K. Effects of strongman training on salivary testosterone levels in a sample of trained men. J Strength Cond Res 2013; 27: 738-747

58 Goldey KL, van Anders SM. Sexual thoughts: links to testosterone and cortisol in men. Arch Sex Behav 2012; 41: 1461-1470

59 Gordon MK, Peloso E, Auker A, Dozier M. Effect of flavored beverage crystals on salivary cortisol enzyme-immunoreactive assay measurements. Dev Psychobiol 2005; 47: 189-195

60 Grace FM, Hayes $L D$, Sculthorpe N. Letter to the Editor: RE: Excessive Sugar Consumption May Be a Difficult Habit to Break: A View From the Brain and Body. J Clin Endocrinol Metab 2015; 100: L56-L57

61 Granger DA, Shirtcliff EA, Booth A, Kivlighan KT, Schwartz EB. The "trouble" with salivary testosterone. Psychoneuroendocrinology 2004; 29: 1229-1240

62 Greaves MS, West HF. Cortisol and cortisone in saliva of pregnancy. J Endocrinol 1963; 26: 189-195

63 Hackney AC, Viru A. Research methodology: endocrinologic measurements in exercise science and sports medicine. J Athl Train 2008; 43: 631-639

64 Hagan RD, Diaz FJ, Horvath SM. Plasma volume changes with movement to supine and standing positions. J Appl Physiol Respir Environ Exerc Physiol 1978; 45: 414-417

65 Hamilton LD, Rellini AH, Meston CM. Cortisol, sexual arousal, and affect in response to sexual stimuli. J Sex Med 2008; 5: 2111-2118

66 Hansen AM, Garde AH, Persson R. Sources of biological and methodological variation in salivary cortisol and their impact on measurement among healthy adults: A review. Scand J Clin Lab Invest 2008; 68: $448-458$

67 Harman SM, Metter EJ, Tobin JD, Pearson J, Blackman MR. Longitudinal effects of aging on serum total and free testosterone levels in healthy men. J Clin Endocrinol Metab 2001; 86: 724-731
68 Hasegawa M, Toda M, Morimoto K. Changes in salivary physiological stress markers associated with winning and losing. Biomed Res 2008; 29: $43-46$

69 Hayes LD, Grace FM, Baker JS, Sculthorpe N. Exercise-induced responses in salivary testosterone, cortisol, and their ratios in men: a meta-analysis. Sports Med 2015; 45: 713-726

70 Hayes LD, Grace FM, Kilgore JL, Young JD, Baker JS. Diurnal variation of cortisol, testosterone, and their ratio in apparently healthy males. Sport SPA 2012; 9: 5-13

71 Hayes LD, Grace FM, Sculthorpe N, Herbert P, Kilduff LP, Baker JS. Does chronic exercise attenuate age-related physiological decline in males? Res Sports Med 2013; 21: 343-354

72 Hayes LD, Grace FM, Kilgore JL, Young JD, Baker JS. Salivary hormone response to maximal exercise at two time points during the day Sport SPA 2013; 10: 25-30

73 Hayes LD, Grace FM, Sculthorpe N, Herbert P, Ratcliffe JW, Kilduff LP, Baker JS. The effects of a formal exercise training programme on salivary hormone concentrations and body composition in previously sedentary aging men. Springerplus 2013; 2 : 18

74 Hayes LD, Sculthorpe N, Grace FM. A commentary on "Testosterone and cortisol jointly modulate risk-taking" by P.H. Mehta, K.M. Welker, S. Zilioli, J.M. Carre, Psychoneuroendocrinology, 2015, 56, 88-99. Psychoneuroendocrinology 2016; 63: 380-381

75 Hayes $L D$, Sculthorpe N, Grace FM. Re: Emotions, immunity and sport: Winner and loser athlete's profile of fighting sport. Brain Behav Immun 2015; 47: 238

76 Hayes $L D$, Sculthorpe $N$, Herbert P, Baker JS, Hullin DA, Kilduff LP, Grace $F M$. Poor levels of agreement between serum and saliva testosterone measurement following exercise training in ageing men. Aging Male 2015; 18: 67-70

77 Hayes $L D$, Sculthorpe N, Herbert P, Baker JS, Hullin DA, Kilduff LP, Grace $F M$. Resting steroid hormone concentrations in lifetime exercisers and lifetime sedentary males. Aging Male 2015; 18: 22-26

78 Hayes LD, Sculthorpe N, Herbert P, Baker JS, Hullin DA, Kilduff LP, Reed $D$, Spagna $R$, Grace FM. Salivary testosterone measurement does not identify biochemical hypogonadism in aging men: a ROC analysis. Endocrine 2015; 50: 256-256

79 Hayes LD, Sculthorpe N, Young JD, Baker JS, Grace FM. Critical difference applied to exercise-induced salivary testosterone and cortisol using enzyme-linked immunosorbent assay (ELISA): distinguishing biological from statistical change. J Physiol Biochem 2014; 70: 991996

80 Heikkonen E, Ylikahri R, Roine R, Valimaki M, Harkonen M, Salaspuro $M$. The combined effect of alcohol and physical exercise on serum testosterone, luteinizing hormone, and cortisol in males. Alcohol Clin Exp Res 1996; 20: 711-716

81 Hennig J, Friebe J, Ryl I, Kramer B, Bottcher J, Netter P. Upright posture influences salivary cortisol. Psychoneuroendocrinology 2000; 25 : 69-83

82 Hoffman JR, Maresh CM, Armstrong LE, Gabaree CL, Bergeron MF, Kenefick RW, Castellani JW, Ahlquist LE, Ward A. Effects of hydration state on plasma testosterone, cortisol and catecholamine concentrations before and during mild exercise at elevated temperature. Eur J Appl Physiol 1994; 69: 294-300

83 Huang R, Zheng J, Li S, Tao T, Ma J, Liu W. Characteristics and contributions of hyperandrogenism to insulin resistance and other metabolic profiles in polycystic ovary syndrome. Acta Obstet Gynecol Scand 2015; 94: 494-500

84 Hucklebridge F, Mellins J, Evans P, Clow A. The awakening cortisol response: no evidence for an influence of body posture. Life Sci 2002; 71: 639-646

85 Jensen MA, Mortier L, Koh E, Keevil B, Hyttinen S, Hansen AM. An interlaboratory comparison between similar methods for determination of melatonin, cortisol and testosterone in saliva. Scand J CLin Lab Invest 2014; 74: 454-461

86 Khan-Dawood FS, Choe JK, Dawood MY. Salivary and plasma bound and "free" testosterone in men and women. Am J Obstet Gynecol 1984; 148: 441-445

87 Kivlighan KT, Granger DA, Booth A. Gender differences in testosterone and cortisol response to competition. Psychoneuroendocrinology 2005; 30: 58-71

88 Kivlighan KT, Granger DA, Schwartz EB, Nelson V, Curran M, Shirtcliff $E A$. Quantifying blood leakage into the oral mucosa and its effects on the measurement of cortisol, dehydroepiandrosterone, and testosterone in saliva. Horm Behav 2004; 46: 39-46 
89 Kocalevent RD, Levenstein S, Fliege H, Schmid G, Hinz A, Brahler E, Klapp BF. Contribution to the construct validity of the Perceived Stress Questionnaire from a population-based survey. J Psychosom Res 2007; 63: 71-81

90 Kraemer WJ, Loebel CC, Volek JS, Ratamess NA, Newton RU, Wickham RB, Gotshalk LA, Duncan ND, Mazzetti SA, Gomez AL, Rubin MR, Nindl $B C$, Hakkinen $K$. The effect of heavy resistance exercise on the circadian rhythm of salivary testosterone in men. Eur J Appl Physiol 2001; 84: $13-18$

91 Kwon S, Perera S, Pahor M, Katula JA, King AC, Groessl EJ, Studenski $S A$. What is a meaningful change in physical performance? Findings from a clinical trial in older adults (the LIFE-P study). J Nutr Health Aging 2009; 13: 538-544

92 Lac G, Berthon P. Changes in cortisol and testosterone levels and T/C ratio during an endurance competition and recovery. J Sports Med Phys Fitness 2000; 40: 139-144

93 Landman AD, Sanford LM, Howland BE, Dawes C, Pritchard ET. Testosterone in human saliva. Experientia 1976; 32: 940-941

94 Lazarou S, Reyes-Vallejo L, Morgentaler A. Wide variability in laboratory reference values for serum testosterone. J Sex Med 2006; 3: 1085-1089

95 Lehmann M, Knizia K, Gastmann U, Petersen KG, Khalaf AN, Bauer S, Kerp L, Keul J. Influence of 6 -week, 6 days per week, training on pituitary function in recreational athletes. Br J Sports Med 1993; 27: 186-192

96 Lewis JG. Steroid analysis in saliva: an overview. Clin Biochem Rev 2006; 27: 139-146

97 Leymarie $P$, Roger $M$, Castanie $M$, Scholler R. Circadian variations of plasma testosterone and estrogens in normal men - study by frequent sampling. J Steroid Biochem Mol Biol 1974; 5: 167-171

98 Litman HJ, Bhasin S, Link CL, Araujo AB, McKinlay JB. Serum androgen levels in black, Hispanic, and white men. J Clin Endocrinol Metab 2006; 91: 4326-4334

99 Lovell DI, Cuneo R, Wallace J, McLellan C. The hormonal response of older men to sub-maximum aerobic exercise: The effect of training and detraining. Steroids 2012; 77: 413-418

100 Maresh CM, Whittlesey MJ, Armstrong LE, Yamamoto LM, Judelson DA, Fish KE, Casa DJ, Kavouras SA, Castracane VD. Effect of hydration state on testosterone and cortisol responses to training-intensity exercise in collegiate runners. Int J Sports Med 2006; 27: 765-770

101 Martin CG, Bruce J, Fisher PA. Racial and ethnic differences in diurnal cortisol rhythms in preadolescents: the role of parental psychosocial risk and monitoring. Horm Behav 2012; 61: 661-668

102 Maso F, Lac G, Filaire E, Michaux 0, Robert A. Salivary testosterone and cortisol in rugby players: correlation with psychological overtraining items. Br J Sports Med 2004; 38: 260-263

103 Matsumoto AM, Bremner WJ. Serum testosterone assays - accuracy matters. J Clin Endocrinol Metab 2004; 89: 520-524

104 Matsumoto K, Takeyasu K, Mizutani S, Hamanaka Y, Uozumi T. Plasma testosterone levels following surgical stress in male patients. Acta Endocrinol 1970; 65: 11-17

105 McLellan CP, Lovell DI, Gass GC. Creatine kinase and endocrine responses of elite players pre, during, and post rugby league match play. J Strength Cond Res 2010; 24: 2908-2919

106 Melin EO, Thunander M, Landin-Olsson M, Hillman M, Thulesius HO. Depression, smoking, physical inactivity and season independently associated with midnight salivary cortisol in type 1 diabetes. BMC Endocr Disord 2014; 14: 75

107 Mindell JS, Coombs N, Stamatakis E. Measuring physical activity in children and adolescents for dietary surveys: practicalities, problems and pitfalls. Proc Nutr Soc 2014; 73: 218-225

108 Mitter PR, Krishnan S, Bell P, Stewart R, Howard RJ. The effect of ethnicity and gender on first-contact rates for schizophrenia-like psychosis in Bangladeshi, Black and White elders in Tower Hamlets, London. Int J Geriatr Psychiat 2004; 19: 286-290

109 Morley JE, Perry HM $3^{\text {rd }}$, Patrick P, Dollbaum CM, Kells JM. Validation of salivary testosterone as a screening test for male hypogonadism. Aging Male 2006; 9: 165-169

110 Muller M, den Tonkelaar I, Thijssen JH, Grobbee DE, van der Schouw YT. Endogenous sex hormones in men aged $40-80$ years. Eur J Endocrinol 2003; 149: 583-589

111 Nater UM, Maloney E, Boneva RS, Gurbaxani BM, Lin JM, Jones JF, Reeves WC, Heim C. Attenuated morning salivary cortisol concentrations in a population-based study of persons with chronic fatigue syndrome and well controls. J Clin Endocrinol Metab 2008; 93: 703-709
112 Nater UM, Youngblood LS, Jones JF, Unger ER, Miller AH, Reeves WC, Heim C. Alterations in diurnal salivary cortisol rhythm in a population-based sample of cases with chronic fatigue syndrome. Psychosom Med 2008; 70: 298-305

113 Neave $N$, Wolfson $S$. Testosterone, territoriality, and the 'home advantage'. Physiol Behav 2003; 78: 269-275

114 Nieman LK, Biller BMK, Findling JW, Newell-Price J, Savage MO, Stewart PM, Montori VM. The diagnosis of Cushing's syndrome: An endocrine society clinical practice guideline. J Clin Endocrinol Metab 2008; 93: 1526-1540

115 Palmieri S, Morelli V, Polledri E, Fustinoni S, Mercadante R, Olgiati L, Eller Vainicher C, Cairoli E, Zhukouskaya VV, Beck-Peccoz P, Chiodini I. The role of salivary cortisol measured by liquid chromatographytandem mass spectrometry in the diagnosis of subclinical hypercortisolism. Eur J Endocrinol 2013; 168: 289-296

116 Panizzon MS, Hauger R, Jacobson KC, Eaves LJ, York TP, Prom-Wormley E, Grant MD, Lyons MJ, McKenzie R, Mendoza SP, Xian H, Franz CE, Kremen WS. Genetic and environmental influences of daily and intraindividual variation in testosterone levels in middle-aged men. Psychoneuroendocrinology 2013; 38: 2163-2172

117 Papacosta E, Nassis GP. Saliva as a tool for monitoring steroid, peptide and immune markers in sport and exercise science. J Sci Med Sport 2011; $14:$ 424-434

118 Pardridge WM, Demers LM. Bioavailable testosterone in salivary glands. Clin Chem 1991; 37: 139-140

119 Persky H, Lief HI, Strauss D, Miller WR, O'Brien CP. Plasma testosterone level and sexual behavior of couples. Arch Sex Behav 1978; 7: 157173

120 Persson $R$, Garde AH, Hansen AM, Osterberg $K$, Larsson B, Orbaek $P$, Karlson $B$. Seasonal variation in human salivary cortisol concentration. Chronobiol Int 2008; 25: 923-937

121 Rausch J, Gabel A, Nagy K, Kleindienst N, Herpertz SC, Bertsch K. Increased testosterone levels and cortisol awakening responses in patients with borderline personality disorder: gender and trait aggressiveness matter. Psychoneuroendocrinology 2015; 55: 116127

122 Rilling JK, Worthman CM, Campbell BC, Stallings JF, Mbizva M. Ratios of plasma and salivary testosterone throughout puberty: production versus bioavailability. Steroids 1996; 61: 374-378

123 Rivier C, Rivest S. Effect of stress on the activity of the hypothalamicpituitary-gonadal axis: peripheral and central mechanisms. Biol Reprod 1991; 45: 523-532

124 Rosner W, Auchus RJ, Azziz R, Sluss PM, Raff H. Position statement: Utility, limitations, and pitfalls in measuring testosterone: an Endocrine Society position statement. J Clin Endocrinol Metab 2007; 92: 405-413

125 Rosner $W$, Vesper $H$. Toward excellence in testosterone testing: a consensus statement. J Clin Endocrinol Metab 2010; 95: 4542-4548

126 Russell E, Koren G, Rieder M, Van Uum S. Hair cortisol as a biological marker of chronic stress: current status, future directions and unanswered questions. Psychoneuroendocrinology 2012; 37: 589-601

127 Salvador A, Suay F, Gonzalez-Bono E, Serrano MA. Anticipatory cortisol, testosterone and psychological responses to judo competition in young men. Psychoneuroendocrinology 2003; 28: 364-375

128 Santner SJ, Albertson B, Zhang GY, Zhang GH, Santulli M, Wang C, Demers LM, Shackleton C, Santen RJ. Comparative rates of androgen production and metabolism in Caucasian and Chinese subjects. J Clin Endocrinol Metab 1998; 83: 2104-2109

129 Sharma M, Palacios-Bois J, Schwartz G, Iskandar H, Thakur M, Quirion $R$, Nair NPV. Circadian rhythms of melatonin and cortisol in aging. Biol Psychiatry 1989; 25: 305-319

130 Shattuck EC, Muehlenbein MP. Mood, behavior, testosterone, cortisol, and interleukin- 6 in adults during immune activation: a pilot study to assess sickness behaviors in humans. Am J Hum Biol 2015; 27: 133-135

131 Shirtcliff EA, Granger DA, Likos A. Gender differences in the validity of testosterone measured in saliva by immunoassay. Horm Behav 2002; 42: 62-69

132 Skarda ST, Burge MR. Prospective evaluation of risk factors for exercise-induced hypogonadism in male runners. West J Med 1998; 169 : 9-12

133 Spratt DI. Altered gonadal steroidogenesis in critical illness: is treatment with anabolic steroids indicated? Best Pract Res Clin Endocrinol Metab 2001; 15: 479-494

134 Spratt DI, Cox P, Orav J, Moloney J, Bigos T. Reproductive axis suppression in acute illness is related to disease severity. J Clin Endocrinol Metab 1993; 76: 1548-1554 
135 Spratt DI, Longcope C, Cox PM, Bigos ST, Wilbur-Welling C. Differential changes in serum concentrations of androgens and estrogens (in relation with cortisol) in postmenopausal women with acute illness. J Clin Endocrinol Metab 1993; 76: 1542-1547

136 Steptoe A, Ussher M. Smoking, cortisol and nicotine. Int J Psychophysiol 2006; 59: 228-235

137 Stone AA, Schwartz JE, Smyth J, Kirschbaum C, Cohen S, Hellhammer $D$, Grossman $S$. Individual differences in the diurnal cycle of salivary free cortisol: a replication of flattened cycles for some individuals. Psychoneuroendocrinology 2001; 26: 295-306

138 Szydlarska D, Grzesiuk W, Kondracka A, Bartoszewicz Z, Bar-Andziak $E$. Measuring salivary androgens as a useful tool in the diagnosis of polycystic ovary syndrome. Endokrynol Pol 2012; 63: 183-190

139 Teo W, McGuigan MR, Newton MJ. The effects of circadian rhythmicity of salivary cortisol and testosterone on maximal isometric force, maximal dynamic force, and power output. J Strength Cond Res 2011; 25: $1538-1545$

140 Thompson WO, Thompson PK, Dailey ME. The effect of posture upon the composition and volume of the blood in man. J Clin Invest 1928; 5: 573-604

141 Thorpe R, Sunderland C. Muscle damage, endocrine, and immune marker response to a soccer match. J Strength Cond Res 2012; 26: 2783-2790

142 Toone RJ, Peacock OJ, Smith AA, Thompson D, Drawer S, Cook C, Stokes $K A$. Measurement of steroid hormones in saliva: Effects of sample storage condition. Scand J Clin Lab Invest 2013; 73: 615-621

143 Trumble BC, Brindle E, Kupsik M, O'Connor KA. Responsiveness of the reproductive axis to a single missed evening meal in young adult males. Am J Hum Biol 2010; 22: 775-781

144 Ussher M, West R, Evans P, Steptoe A, McEwen A, Clow A, Hucklebridge $F$. Reduction in cortisol after smoking cessation among users of nicotine patches. Psychosom Med 2006; 68: 299-306

145 Valero-Politi J, Fuentes-Arderiu X. Within- and between-subject biological variations of follitropin, lutropin, testosterone, and sex-hormone-binding globulin in men. Clin Chem 1993; 39: 1723-1725

146 Vasaghi-Gharamaleki B, Mirzaii-Dizgah I. Unstimulated whole saliva cortisol levels during Ramadan in Iranian Muslims. J Contemp Dent Pract 2014; 15: 341-344

147 Vervoorn C, Quist AM, Vermulst LJM, Erich WBM, Devries WR, Thijssen $J H H$. The behavior of the plasma-free testosterone cortisol ratio during a season of elite rowing training. Int J Sports Med 1991; 12: 257-263
148 Volek JS, Kraemer WJ, Bush JA, Incledon T, Boetes M. Testosterone and cortisol in relationship to dietary nutrients and resistance exercise. J Appl Physiol 1997; 82: 49-54

149 Warne GL, Kanumakala S. Molecular endocrinology of sex differentiation. Semin Reprod Med 2002; 20: 169-180

150 Wartofsky L, Handelsman DJ. Standardization of hormonal assays for the 21st century. J Clin Endocrinol Metab 2010; 95: 5141-5143

151 Welker KM, Lozoya E, Campbell JA, Neumann CS, Carre JM. Testosterone cortisol, and psychopathic traits in men and women. Physiol Behav 2014; 129: 230-236

152 West DJ, Cunningham DJ, Finn C, Scott P, Crewther BT, Cook CJ, Kilduff $L P$. The metabolic, hormonal, biochemical and neuromuscular function responses to a backward sled drag training session. J Strength Cond Res 2014; 28: 265-72

153 West DWD, Burd NA, Tang JE, Moore DR, Staples AW, Holwerda AM, Baker SK, Phillips SM. Elevations in ostensibly anabolic hormones with resistance exercise enhance neither training-induced muscle hypertrophy nor strength of the elbow flexors. J Appl Physiol 2010; 108: 60-67

154 Winter DL, Hanlon AL, Raysor SL, Watkins-Bruner D, Pinover WH, Hanks GE, Tricoli JV. Plasma levels of IGF-1, IGF-2, and IGFBP-3 in white and African-American men at increased risk of prostate cancer. Urology 2001; 58: 614-618

155 Wong JA, Pickworth WB, Waters AJ, al'Absi M, Leventhal AM. Cortisol levels decrease after acute tobacco abstinence in regular smokers. Hum Psychopharmacol 2014; 29: 152-162

156 Yie SM, Wang R, Zhu YX, Liu GY, Zheng FX. Circadian variations of serum sex hormone binding globulin binding capacity in normal adult men and women. J Steroid Biochem 1990; 36: 111-115

157 Zhao ZY, Xie Y, Fu YR, Li YY, Bogdan A, Touitou Y. Circadian rhythm characteristics of serum cortisol and dehydroepiandrosterone sulfate in healthy Chinese men aged 30 to 60 years. A cross-sectional study. Steroids 2003; 68: 133-138

158 Zilioli S, Watson NV. Winning isn't everything: mood and testosterone regulate the cortisol response in competition. PLoS One 2013; 8: e52582 